$200 \mu \mathrm{gm} . / \mathrm{ml}$. However, slight depression of growth was observed at $8 \mu \mathrm{gm} . / \mathrm{ml}$.

The suppressive effect on the growth of the pathogen in living tissue was tested further by inoculation of cut tuber surfaces treated with streptomycin solutions and rinsed to remove free antibiotic. It was found that higher concentrations were re. quired to obtain a checking effect in this work. A slight depression of sporulation occurred at $60 \mu \mathrm{gm} . /$ ml., and complete inhibition was observed at 200 $\mu \mathrm{gm} . / \mathrm{ml}$.

It appears that when absorbed by the host cell streptomycin is firmly held, since there is little movement to tissue developed after the plant is removed from treated to normal nutrient solutions. Thus in one series of plants, Phytophthora developed rapidly on axillary shoots, but there was a slight reduction of sporulation on the basal leaves indicating that some translocation may have occurred.

There is a difference in response between organs of treated plants, the effect being more marked in leaves of both potato and tomato than in tubers or fruits. There are indications that young leaves respond more definitely than older ones.

Streptomycin does not exert a general protective effect against fungal pathogens. Even when treated with a concentration of $100 \mu \mathrm{gm} . / \mathrm{ml}$., many potato plants were severely attacked by powdery mildew (Erysiphe solani Vanha.).

If one assumes that streptomycin is evenly distributed within the cell and total extraction of streptomycin is obtained, the concentrations demonstrated by bio-assay of tissue extracts cannot be responsible for the effects observed. It would appear, then, that the antibiotic is either: (a) unevenly distributed in such a way that the parasite contacts lethal concentrations at the surface of the cell where parasite and host plasm first establish contact; or (b) it induces some change which alters the hostpathogen relationship in such a way as to confer some degree of resistance to the host.

Further experimental work will be required for the elucidation of the mechanisms involved in these changes of the host-pathogen relationship.

K. O. Muller

J. H. E. Mackay

J ANET N. Friend

Division of Plant Industry,

Commonwealth Seientific and

Industrial Research Organization, Canberra.

July 12.

${ }^{2}$ Bonde, R., Phytopathology, 43, 463 (1953).

\section{Reaction between Phthalein Dyes and Heated Foodstuffs}

A Tentative method for the estimation of the quality of soybean oil meal, based on varying ability of different meals to absorb or react with phenolphthalein, has been briefly described ${ }^{1}$. Properly heated meals absorbed or reacted with significantly more phenolphthalein than under-heated samples, and over-heated samples somewhat more than the properly heated ones.

Since then, a variety of other dyes has been tried, but it was found that only phthaleins like phenol. phthalein, phenol red, bromothymol blue, and cresol red reacted in this characteristic way. Other dyestuffs tried-methyl red, methylene blue, fuchsin-were ab- sorbed to about the same extent regardless of the heat treatment of the meals. Further, it was found that the absorption of the phthalcin dyes was rather independent of the fineness of the sample. From these facts it is concluded that there is not only an absorption but also a staining reaction between the phthalein dyes and substances in the soybean oil meal, especially those formed by heating (the Browning reaction).

From the experiments with the different phthalein dyes it has been found that phenolphthalein under given conditions best distinguishes between underheated, properly heated and over-heated meals. It has, however, the disadvantage of not being stable when made alkaline in presence of substances present in soybean oil meal. The solution must be made alkaline immediately before the reading in the photometer. It is supposed that the substances in the alkaline medium form products which react with phenolphthalein. Cresol red is much more stable, and when using this dye the method has been simplified as follows : $400 \mathrm{mgm}$. samples are weighed in centrifuge tubes and $10 \mathrm{ml}$. freshly mixed reagent solution (one part of an alcoholic solution of cresol red, $2 \mathrm{mgm} . / \mathrm{ml}$., and nine parts of $0 \cdot 1 \mathrm{~N}$ hydrochloric acid) are added. The tubes are shaken for one hour and then centrifuged. One ml. of the supernatant is added to $10 \mathrm{ml}$. $0.02 \mathrm{~N}$ sodium hydroxide. The colour is read in a spectrophotometer at 5,700 A.

Some results from the experiments with this method are given in Table 1. From this it is seen that there is a marked tendency of heated meals to absorb (react with) more cresol red as compared with under-heated samples.

Table 1. Absorption of Cresol Red by Different Soybean OJl

\begin{tabular}{|c|c|c|c|}
\hline $\begin{array}{l}\text { Character of the } \\
\text { soybean oil meal* }\end{array}$ & $\begin{array}{l}\text { Number } \\
\text { of meals } \\
\text { tested }\end{array}$ & $\begin{array}{c}\text { Photometer } \\
\text { readings } \\
\text { (\% transmission) }\end{array}$ & $\begin{array}{l}\text { Mgm. cresol } \\
\text { red absorbed } \\
\text { per gm. meal }\end{array}$ \\
\hline $\begin{array}{l}\text { Much under-heated } \\
\text { Under-heated } \\
\text { Properly heated } \\
\text { Over-heated }\end{array}$ & $\begin{array}{l}6 \\
4 \\
8 \\
2\end{array}$ & $\begin{array}{r}9-15 \\
21-28 \\
39-52 \\
54-55\end{array}$ & $\begin{array}{l}2 \cdot 5-3 \cdot 0 \\
3 \cdot 3-3 \cdot 8 \\
4 \cdot 0-4 \cdot 3 \\
4 \cdot 4-4 \cdot 5\end{array}$ \\
\hline
\end{tabular}

- As indicated from laboratory determinations and chick growth experiments.

This cresol red test has also been performed with some samples of rape seed meal, linseed meal and dried milk. Even with these, correlation between heat treatments and cresol red absorption was found. Details of these experiments will be published elsewhere.

National Animal Experiment Station,

Allan Frölich Uppsala 7.

June 29.

${ }^{1}$ Frölich, A., Lantbruksakad. tidskr., 92, 367 (1953); Nature, 173 , 132 (1954).

\section{Induction of Tumours with} I-(2-Tolylazo)-2-naphthol (Oil Orange TX)

PEACock $^{1}$ induced hepatomas in seven of seventeen mice surviving subcutaneous injection of oil orange $E$ (1-benzeneazo-2-naphthol) for more than fourteen months. This substance was then in use as a food dye. Clayson ${ }^{2}$ has since suggested that it might be active by virtue of its in vivo reduction to 1 -amino-2naphthol. If this be so, it was thought that other compounds capable of being reduced to this amino. naphthol might be earcinogenic. 